\title{
Relationship between Physical Health and Stress Level of Urban and Rural Working and Non Working Post-Menopausal Women
}

\author{
Badami, $\mathrm{S}^{1}$.,Hundekar,P, $\mathrm{S}^{2}$.,Itagi, $\mathrm{S}^{3}$ and Yenagi, $\mathrm{G}, \mathrm{V}^{4}$ \\ IPh D Scholar, Dept of Human Development and Family Studies, College of Rural home Science, University of \\ Agricultural Sciences, Dharwad \\ 2Ph D Scholar, Dept of Human Development and Family Studies, College of Rural home Science, University of \\ Agricultural Sciences, Dharwad \\ 3Associate Professor, Dept of Human Development and Family Studies, College of Rural home Science, \\ University of Agricultural Sciences, Dharwad \\ 4 Associate Professor of Psychology, College of agriculture, University of Agricultural Sciences, Dharwad
}

\begin{abstract}
One hundred twenty employed and non-employed post-menopausal women from rural and urban locality were selected by purposive sampling method from Dharwad Taluka. The data was collected by personal interview from 60 urban employed \& non-employed and 60 rural employed \& non-employed post-menopausal women with mean age of 44.5. Physical and General Health Inventory (PGI) developed by Wig and Verma (1978), Stress Index Questionnaire by Ivancevich and Matteson (1980) and Socio-Economic Status Scale developed by O.P.Agarwal (2005) were used for the study. Results showed that $41.66 \%$ urban women belonged to high SES group followed by $36.66 \%$ in upper high SES group, while $33.34 \%$ of rural women belonged to lower middle SES group followed by $28.34 \%$ in upper middle SES group. Significant difference was found in the physical health status of urban employed and non employed postmenopausal women, whereas no such differences were observed between rural employed and non employed women. Significantly a higher percentage of urban employed women (63.34\%) were severely affected by different physical problems as compared to rural employed women $(46.66 \%)$. Higher percentage of the urban non employed women (90\%) found to have severely affected physical health status, whereas only $50 \%$ of rural non employed women fell in this category. Though $73.34 \%$ of urban employed \& $45 \%$ rural employed women belonged to high \& upper middle socio economic group most of the post-menopausal women expressed about having severe physical health problems like backache, insomnia, dizziness, weakness, eye problem, sweating, uneasiness, irritability and loss of memory. It was found that, there is a significant relationship between physical health, stress and socio economic status of both urban and rural women.
\end{abstract}

Keywords: Age of menopause, Menopause, Postmenopausal health, Quality of life; Urban and Rural Indian women, Women health

\section{Introduction}

Women plays a very important role in the Indian society. She has got different roles to play in family from her birth as a daughter, sister, wife, mother, grandmother till the end of her life which involves greater responsibilities. Development entails many changes. The outstanding age-related event in middle adulthood is menopause. The word menopause comes from the Greek words "menos" and "pause".

The term menopause means the end of the monthly menstrual cycle which is the central external marker of human female fertility. All women who live long enough will make transition to menopause (Wong et al., 2001). The menopausal ages were range from 40 to 50 years. During a woman's reproductive years, the follicles of the ovaries, under the stimulation of hormones released by the pituitary gland, periodically rupture and discharge their ova (eggs).Menopausal symptoms can really have an important impact in the daily, social and sexual life of postmenopausal women Hassa et al., (2005). Numerous factors including menopausal status, social background, and education, physical and emotional health may influence women's knowledge and believes about menopause (Theisen et al., 1995; Avis and Mckinley, 1991).

The dual role of taking care of familial as well as professional jobs has created stress in the life of women. The stress of women affects their physical and psychological health status.Few Indian studies have attempted to determine the rural-urban difference in menopausal age and symptoms. Thus, the present study sought to examine the variations in menopausal characteristics between urban and rural working \& non-working women and how these characteristics can be predicted from differential socio-demographic variables. 


\section{Methodology}

A descriptive study was conducted during 2013 in urban and rural areas of Dharwad city. A randomised population of total 120 women who had attained menopause. The information was collected from the women who had completed at least 5 years of menopausal period. Urban non working population comprise of 30 respondent taken from the Sandankeri area of Dharwad city while same number of rural non working women from Yattingudda village, Dharwad. Whereas, the urban and rural employed women 30 each were selected from University of Agricultural science, campus Dharwad. A pre-designed questionnaire was distributed to participants except for the illiterate. Respondents were asked to fill the questionnaire without leaving any question and, personal interview method was used to collect the required information from illiterate. General information pretested schedule consisted of items to elicit auxiliary information of the subjects regarding age, gender, family composition and health. Socio Economic Status Scale (Aggarwal et al., 2005) was employed to assess the SES of the family, Physical and General Health, PGI (Wig and Verma 1978) scale was used to assess the general physical health status of post menopausal women and Stress Index Questionnaire (Ivancevich and Matteson, 1980) was used to assess the general stress level of post menopausal women from both rural and urban area. Karl Pearson's correlation coefficient analysis was carried out to assess the degree of relationship between physical, stress and socio-economic status.

\section{Results And Discussion}

Table 1 shows that most of the respondents of both urban and rural women perceived that they were having severe health problems like backache, insomnia, dizziness, weakness, eye problem, sweating, uneasiness, irritability, loss of memory. Significant difference in the health status was observed between the urban working and non working postmenopausal women. Whereas there was no significant difference was observed between rural working and non working postmenopausal women. Higher per centage $(90 \%)$ of the urban non working women's health was severely affected and $63.34 \%$ of the urban working women's health was severely affected. Whereas only $46.66 \%$ of the rural working women's health was severely affected and $50 \%$ of the rural non working women's health was severely affected. While $15 \%$ of the rural non working women's health was mildly affected. These findings are in agreement with the inferences drawn in the studies of Christian et.al (2011), Nagar and Dave(2005) and Sharma et.al(2007)

Table 2 illustrates significant correlation between the aspects such as physical health, stress and socio economic status of the post menopausal women. Physical health condition of women was negatively correlated with stress and showed positive relationship with socio economic status. So we can say that, as the physical health of women improves, the stress in her daily life will get decreases and increased economic status of post menopausal women makes her physically fit. Noticeably it was found that, increased socio economic status of women lead to increased stress level. It might be due to the selection of highly earning samples for the study such as, University professors form the urban and labourers as well as assistants working in the university who were belonged to the rural locality. These findings are in agreement with the inferences drawn in the studies Sengupta and Srinivasan(2010).

\section{Conclusion}

The present study revealed mean age at menopause to be 48 years. Most frequent menopausal symptoms were back pain, irritation of the eye, insomnia, fatigue and lack of energy followed by headache, hot flushes, cold sweats, and cold hand and feet. Analysis demonstrated that working women had a better menopausal age, specific quality of life in comparison with their non-working counterpart. The findings were in close agreement with other studies. The poor quality of life among non-working group of women was likely to be associated with their lack of economic independence, which reduces the possibility of availing health-care services. In rural areas, women have more limited access to food, education and medical care, and increased physical and mental health risk because of the existence of gender-based social, cultural and economic inequalities; however. It was found that women reported wide range of problems, both physical and psychological such as backache, uneasiness, profuse perspiration, fatigue, increased headache, hot flushes and sleep disturbances during the menopausal period. In addition to it, the factors affecting the differential perceptions need to be investigated in order to understand the phenomenon of menopause better and use the understanding to promote the well being of women concerned. 
Table 1 Health status of postmenopausal working and non working women of urban and rural areas

\begin{tabular}{|c|c|c|c|c|c|c|c|c|}
\hline \multirow[t]{2}{*}{ Location } & \multirow[t]{2}{*}{ samples } & \multicolumn{3}{|c|}{ Health status } & \multirow{2}{*}{$\begin{array}{l}\text { Total } \\
(\%)\end{array}$} & \multirow[t]{2}{*}{ Mean \pm SD } & \multirow{2}{*}{\multicolumn{2}{|c|}{ t value }} \\
\hline & & Mild & Moderate & Severe & & & & \\
\hline \multirow[t]{2}{*}{$\operatorname{Urban}(n=60)$} & working $(\mathrm{n}=30)$ & - & $\begin{array}{c}11 \\
(36.66)\end{array}$ & $\begin{array}{c}19 \\
(63.34)\end{array}$ & $\begin{array}{c}30 \\
(100.00)\end{array}$ & $\underline{2.62 \pm 8.67}$ & & \\
\hline & $\begin{array}{c}\text { Non working } \\
(\mathrm{n}=30)\end{array}$ & - & $\begin{array}{c}03 \\
(10.00) \\
\end{array}$ & $\begin{array}{c}27 \\
(90.00) \\
\end{array}$ & $\begin{array}{c}30 \\
(100.00) \\
\end{array}$ & $1.13 \pm 11.28$ & $1.872 *$ & \\
\hline \multirow[t]{2}{*}{ Rural (n=60) } & working $(n=30)$ & $\begin{array}{c}09 \\
(30.00)\end{array}$ & $\begin{array}{c}07 \\
(23.10)\end{array}$ & $\begin{array}{c}14 \\
(46.66)\end{array}$ & $\begin{array}{c}30 \\
(100.00)\end{array}$ & $1.12 \pm 4.49$ & & $\underline{0.813 \mathrm{NS}}$ \\
\hline & $\begin{array}{l}\text { Non working } \\
(\mathrm{n}=30)\end{array}$ & $\begin{array}{c}15 \\
(50.00)\end{array}$ & - & $\begin{array}{c}15 \\
(50.00)\end{array}$ & $\begin{array}{c}30 \\
(100.00)\end{array}$ & $1.31 \pm 15.36$ & $0.66 \mathrm{NS}$ & \\
\hline Total (\%) & 120 & $\begin{array}{c}24 \\
(20.00)\end{array}$ & $\begin{array}{c}21 \\
(17.50)\end{array}$ & $\frac{75}{(62.50)}$ & $\begin{array}{c}120 \\
(100.00)\end{array}$ & & & \\
\hline
\end{tabular}

Figures in the parenthesis indicates percentages , ${ }^{*}$ Significant at 0.05 level of probability, NS: Not Significant

Table 2 Interrelationship between physical health, stress and SES of working and non working post menopausal women

\begin{tabular}{|c|c|c|c|}
\hline "r" value & Physical health & Stress & SES \\
\hline Physical health & 1 & $-0.379 * *$ & 0.148 \\
\hline Stress & $-0.379 * *$ & 1 & $0.540 * *$ \\
\hline SES & 0.148 & $0.540 * *$ & 1 \\
\hline
\end{tabular}

\section{References}

[1]. Avis, N. E., \& McKinley, S. M. (1991). A longitudinal analysis of women's attitudes toward the menopause: results from the Massachusetts Women's Health Study. Maturitas, 13(1), 65-79. http://dx.doi.org/10.1016/ 0378-5122(91)90286-Y

[2]. Atkinson, C., Compston, E.J., Day, E.N., Dowsett, M. and Bingham, A.S., (2004). The effects of phytoestrogen isoflavones on bone density in women : a double blind, randomized, placebo-controlled trial. American J. Clin. Nutr., 79:326- 333.

[3]. Christian D., Kathad M. And Bhavsar B.(2011). Socio-demographic characteristics of postmenopausal women of rural area of vadodara district, gujarat, National Journal of Community Medicine Vol 2 Issue 3

[4]. Hassa, H., Tanir, H. M., Yildrim, A., Senses, T., Oge, T., \& Mutlu, F. S. (2005). Associated factors with urogenital score in natural and surgical menopause. Maturitas, 16(52), 65-9.

[5]. http://dx.doi.org/10.1016/j.maturitas.2004.12.005

[6]. Ivancevich, J.M. and M.T. Matteson (1980). Stress and Work, A Managerial Perspective, Glenview, IL: Scott, Foresman and Company.

[7]. Kaira, S. and Wadhwa, P., (2002), Osteoporosis in post menopausal women. Obstetrics and Gynaecology, 7 (12) : $703-706$.

[8]. Nagar S. and Dave P., (2005). Perception of Women Towards Physiological Problems Faced at Menopause, J. Anthropologist, KREpublishers 7(3): 173-175 (2005).

[9]. Neeru Sharma, Sumati Vaid and Anju Manhas(2005).Age at Menopause in Two Caste Group (Brahmins and Rajputs) From Rural Areas of Jammu, $J$. Anthropologist, KRE publishers, 7(2): 111-113 (2005).

[10]. Obermeyer, C.M., (2002). Menopause in Morocco : Symptomatology and medical management. Maturitas, 41: 87-95.

[11]. O.P. Aggarwal, S.K. Bhasin, A.K. Sharma, P. Chhabra, K. Aggarwal, O.P. Rajoura (2005-10 - 2005-12). A New Instrument (Scale) for Measuring the Socioeconomic Status of a Family: Preliminary Study. Indian Journal of Community Medicine. Vol. 30, No. 4 (2005-10 - 2005-12)

[12]. Sengupta A. And Srinivasan N.,(2010). Predicting menopausal health in a diverse population group through a theoretical linear model, HEALTH. Vol.2, No.11, 1320-1326

[13]. Sharma S, Tandon R.V. and Mahajan A.(2007). Menopausal symptoms in urban women. JK science. Vol. 9 No. 1, January-March 2007

[14]. Telaprolu, N. and George, R., (2005). Stressors and their sources in employment organization- development of Employment Organization Sources of Stressors Scale (EOSS).

[15]. Theisen, S. C., Mansfield, P. K., Seery, B. L., \& Voda, A. (1995). Predictors of midlife women's attitudes towards menopause. Health Values, 19(3), 22-31.

[16]. Vijayalakshmi S., Chandrababu, R. and Victoria, E. L. , (2013). Menopausal transition among northern Indian women. Nitte Univ. J. Health Sc. 3 (2): 73-79.

[17]. Wig, N.N. and Verma, S.K., (1978). Post Graduate Inst. Medical Edn. Res., Agra Psychol. Res. Cell, Agra (India).

[18]. Wong, S. J., Lue, S. R., Juang, K. D., \& Chiu, L. M. (2001). The Kinmen women-health investigation: a menopauseal study of a population aged 40-54. Maturitas, 39(2), 117-20. http://dx.doi.org/10.1016/S0378-5122(01)00193-1 